\title{
Software Project Management Systems Using Kanban Method in the CV. Primavisi Globalindo
}

Sistem Manajemen Proyek Perangkat Lunak Menggunakan Metode Kanban di CV. Primavisi Globalindo

\author{
Received: \\ 22 April 2020 \\ Accepted: \\ 22 June 2020 \\ Published: \\ 19 August 2020
}

\author{
${ }^{*}$ Muhammad Aliyya Ilmi, ${ }^{2}$ Fajar Pradana, ${ }^{3}$ Widhy Hayuhardhika \\ Nugraha Putra \\ ${ }^{1,2}$ Teknik Informatika, Universitas Brawijaya \\ ${ }^{3}$ Sistem Informasi, Universitas Brawijaya \\ 1,2,3 Malang, Indonesia \\ E-mail: ${ }^{1}$ aliyyailmi20@student.ub.ac.id, ${ }^{2}$ fajar.p@ub.ac.id, \\ 3widhy@ub.ac.id \\ *Corresponding Author
}

\begin{abstract}
Reducing the risk of failure in working on software projects is one of the successes for the company. It can be done by implementing project planning management properly. One important aspect of project management planning is scheduling. Scheduling includes recording human resources and tasks in the project. The Kanban method is one of the methods used to overcome problems in controlling project schedules. This study aims to develop a project scheduling system that applies the Kanban method. In this research, project management and scheduling system will be developed using the Kanban method. This system expected to be able to assist companies in handling projects. Kanban was chosen because it can easily respond to project changes, easily implemented, and company needs. In this study, unit testing was performed on the system's three main features and tested the validity of the system's 49 functional requirements. The usability test produces a value of 76. Based on the validation and usability test results, it can be concluded that the system is included in the acceptable category.
\end{abstract}

Keyword - Project Management, Kanban, Waterfall, Codeigniter, Website Application

Abstrak-Mengurangi resiko kegagalan dalam mengerjakan proyek perangkat lunak merupakan salah satu keberhasilan bagi perusahaan. Hal tersebut dapat dilakukan dengan menerapkan manajemen perencanaan proyek dengan baik. Salah satu aspek penting dalam perencanaan manajemen proyek adalah penjadwalan. Penjadwalan meliputi penjadwalan sumber daya manusia dan tugas-tugas dalam proyek. Metode Kanban merupakan salah satu metode yang digunakan untuk mengatasi permasalahan dalam pengendalian jadwal proyek. Penelitian ini bertujuan untuk mengembangkan sistem penjadwalan proyek yang menerapkan metode Kanban. Dalam penelitian ini akan dikembangkan sistem manajemen dan penjadwalan proyek dengan metode Kanban. Sistem ini diharapkan mampu membantu perusahaan dalam menangani proyek. Kanban dipilih karena mampu merespon perubahan proyek dengan mudah, mudah diterapkan, dan sesuai dengan kebutuhan perusahaan. Dalam penelitian ini dilakukan unit testing terhadap 3 fitur utama sistem dan pengujian validitas terhadap 49 kebutuhan fungsional sistem. Adapun uji usabilitas menghasilkan nilai sebesar 76. Berdasarkan hasil uji validasi dan usabilitas tersebut dapat disimpulkan sistem termasuk dalam kategori dapat diterima.

Kata Kunci-Manajemen Proyek, Kanban, Waterfall, Codeigniter, Aplikasi Website

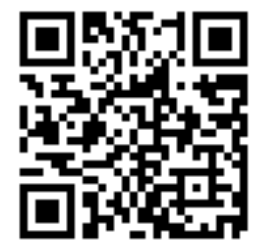


INTENSIF, Vol.4 No.2 August 2020

ISSN: 2580-409X (Print) / 2549-6824 (Online)

DOI: https://doi.org/10.29407/intensif.v4i2.14320

\section{INTRODUCTION}

Management is a spatial planning activity closely related to each scale of life, starting from the smallest things, namely individuals and complex organizations related to the lives of many people, no exception to a company. A company certainly expects all projects handled can be very well managed. To be able to manage the project properly, of course, good project management is also needed[1]. It means it involves superior planning,t mature organizational techniques, as well as directing and controlling company wealth such as available resources to achieve agreed goals within the given timeframe.[2].

In today's dynamic technology-based business environment, companies engaged in the software must be able to answer uncertain customer needs [2]. Unpredictable needs must influence the plans that have been prepared. Changing requirements in the middle of a project must have an impact on project planning. If there are frequent changes that should be minimized in the project work process[3], then it can result in project travel processes hampered. Project changes can be reduced by making accurate project planning. The changes that occur can be handled by using appropriate project management methods and the conditions of the project being managed.

Managing software projects is not easy. The management of this project is increasingly difficult because this process is an attempt to make something invisible visible. Also, the software has unique characteristics such as invisibility, complexity, and flexibility, where it is this character distinguishes software projects from others.[2]. The difficulty of managing a software project often results in a project failing. The case of failure of a software project in Indonesia itself is not exactly small. Based on data, from 110 information system projects in several cities in Indonesia, 27\% of projects were completed with an appropriate budget, did not exceed the time limit, and were assessed by users. As for $55 \%$ of projects experiencing problems, $18 \%$ of plans canceled[4].

One effort that can be done to simplify project management is to use the help of a project management system or tool. A project management system must apply a project management method to be used and visualized in the order. One example of a good way of handling software projects is the Kanban method. Kanban in Japanese means as a card or a sign board[5]. Kanban is a work scheduling system that maximizes team productivity by reducing idle time. Idle time can occur in any process, workflow, or procedure and can usually be tracked based on the process itself[6].

Marko Ikonen et al. (2011) examined the impact of applying the Kanban method in a software project. The research presents an example of applying Kanban manually. An example of 
applying Kanban can be observed in Figure 1. Kanban is applied using a blank board, divided into five parts: backlog, queue, writing, editing, and done. In each section states the stage that must be passed a task. Each section/stage contains one or more notes containing functions that are at that stage. Also, each step there is a number written next to it, which states the maximum limit of tasks at that stage.

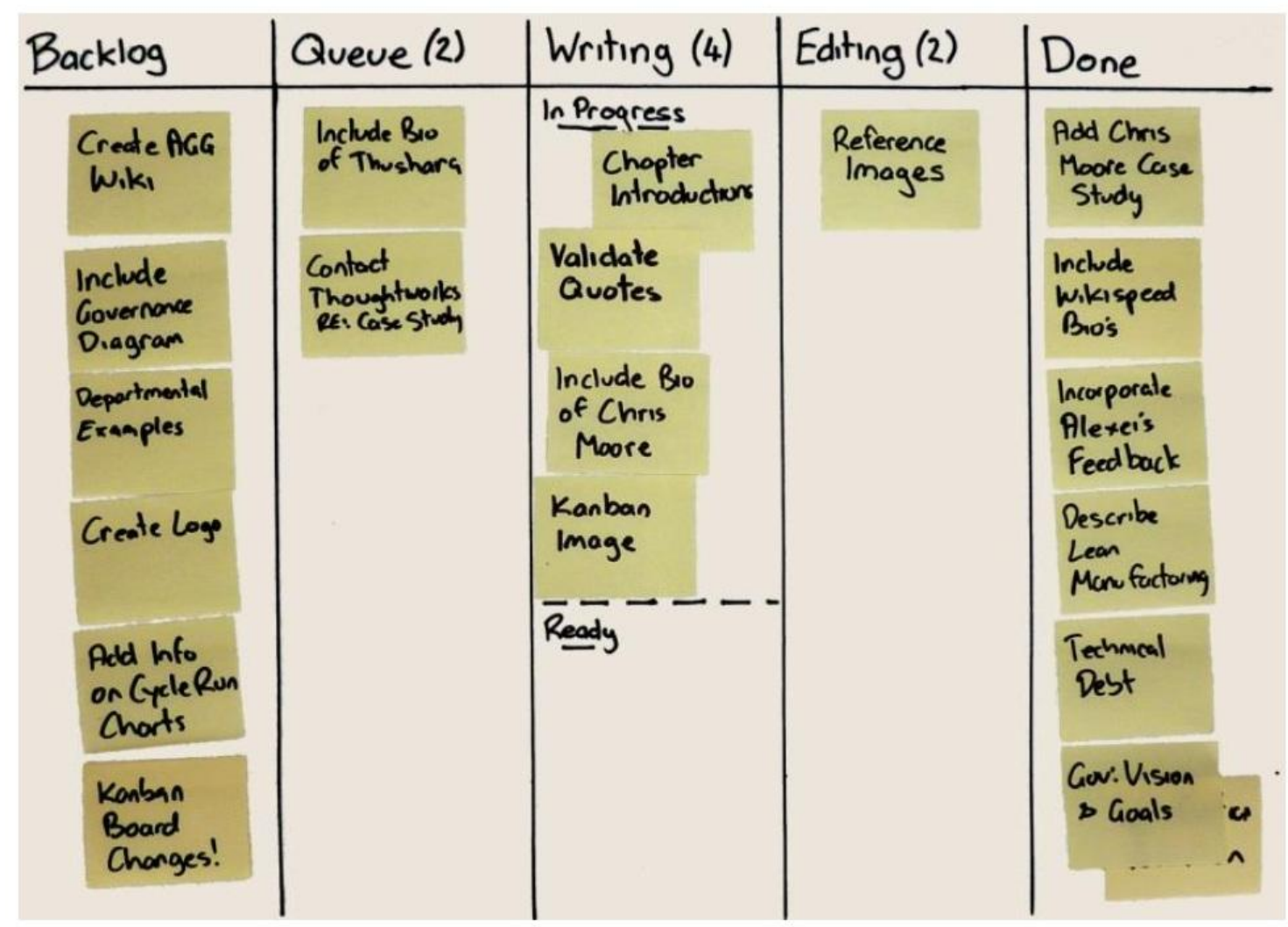

Figure 1. EXAMPLE OF APPLICATION OF KANBAn [7]

According to Marko Ikonen et al., the Kanban method can increase motivation and control over project activities. It happens because the advantage of using Kanban is to visualize the project's entire development at one time[8]. But the Kanban visualization in the study still uses a blank board, so it cannot be accessed anytime by the needy.

Erika Corona and Filippo Eros Pani (2013) review the application of the Lean-Kanban approach that does not have specific standards and rules. These problems are answered through the use of the Kitchenham method. The Kitchenham method is expected to provide perception and understanding of how the Kanban approach is applied to readers and can be used as consideration for developers before deciding to adopt Kanban[9].

Fahat (2018) developed a project management system using the Scrum method. The research presented theories about the Scrum method used as a basis or reference for the development of a 
INTENSIF, Vol.4 No.2 August 2020

ISSN: 2580-409X (Print) / 2549-6824 (Online)

DOI: https://doi.org/10.29407/intensif.v4i2.14320

project management system to convey features that are by the project management cycle with the Scrum method[10]. The result of this research is a project management system that applies Scrum. Unlike the Kanban method, Scrum has complicated artifacts and emphasizes regular development team meetings [11]. The complexity of Scrum is not by the company's business processes, so researchers prefer to use Kanban. According to statistical comparisons, Kanban is preferred over Scrum [12].

The application of Kanban is not limited to software engineering. Several studies state that Kanban has been applied to various types of industries, including aeronautics, finance [13], health [14], human resources, and also in software development [15][16][17]. This study further convinced researchers that Kanban's selection is an appropriate action, and researchers believe that Kanban can assist companies in managing the projects handled.

Based on the description above, the purpose of this study is to build a system or tool in the form of a web-based Project Management Application by applying the Kanban chart scheduling method to the CV. Primavisi Globalindo Surabaya. The purpose of implementing Kanban is to produce scheduling aids that are easier and more effective. The web platform was chosen. It provides ease and flexibility of access for users because it can be accessed anytime and anywhere. This system will be built by excavating the needs of researchers conducted on the CV. Primavisi Globalindo Surabaya. After the order is finished, then usability testing will be carried out by the researchers together with the CV staff. Primavisi Globalindo Surabaya to find out the usability level of the project management system that was built.

\section{RESEARCH METHOD}

\section{A. Waterfall Method}

This research is a development study using the Waterfall method. This method is called Waterfall. The phases of the technique are done sequentially. The results of each step will be used as a start for the next [18] work. The Waterfall method phase starts from the study of literature, requirements engineering, system design, system implementation, system testing, and analysis, and ends with drawing conclusions and suggestions [19]. These stages can be seen in Figure 2. 


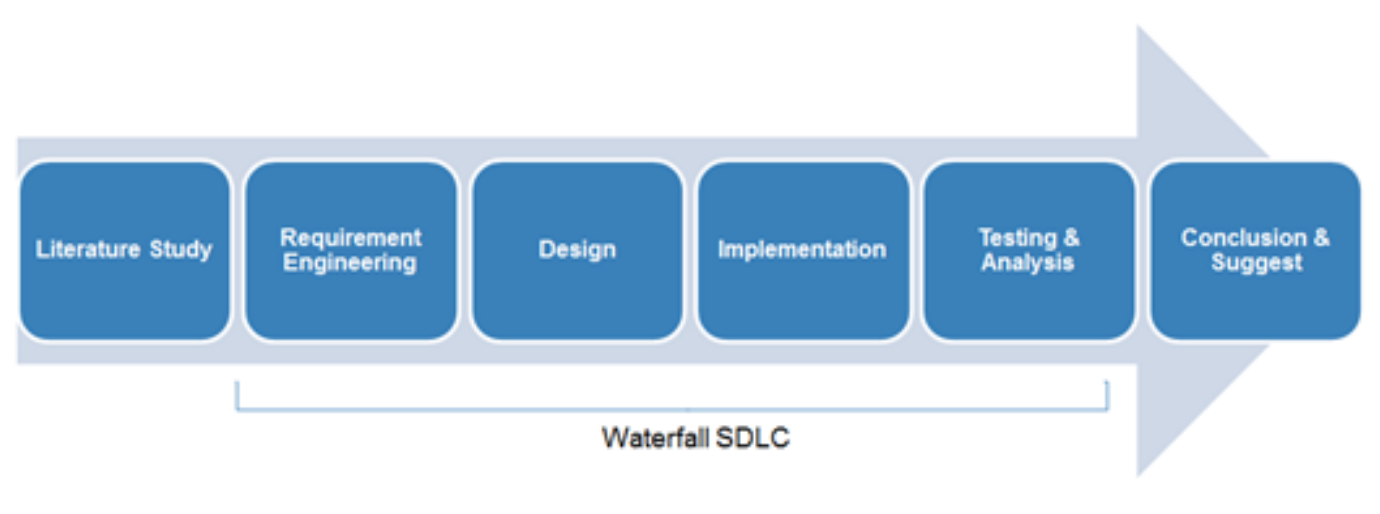

Figure 1. RESEARCH METHOD

\section{Literature Study}

A literature study is a stage carried out to understand and find supporting concepts needed to carry out research. A literature study contains a theoretical basis related to all concepts used in research. This stage is very necessary so that the basic knowledge to build a system is fulfilled properly. Literature studies used in making the design and implementation of this system are obtained from scientific articles, books, theses, and information available on the internet in the form of projects or reports.

\section{Requirement Engineering}

Requirement engineering is implemented to understand the needs that will be needed later in the system development process. The hypothesis of system requirements is formulated at this stage; then, obligations are eliminated or added to suit the system requirements. The objectoriented analysis approach is used to carry out the engineering process. The needs obtained are modeled using UML (Unified Modeling Language) diagrams for modeling needs, namely, use case diagrams. System modeling is done to provide an overview of the interactions that occur within the system. After the use case diagram is formed, the next step is to create a use case scenario to clarify the workflow of the system.

3. Plan

The design is the second step of the Waterfall SDLC model. This stage is carried out after need engineering. The object-oriented design approach will be used to design the system. This approach was chosen because it can describe the system as a collection of objects that can interact with each other and work together to carry out certain tasks. UML diagrams are also used as a system design modeling tool. This process aims to create a blueprint that can be used as a basis for the implementation process. 
INTENSIF, Vol.4 No.2 August 2020

ISSN: 2580-409X (Print) / 2549-6824 (Online)

DOI: https://doi.org/10.29407/intensif.v4i2.14320

\section{Implementation}

Implementation is the third stage of the SDLC Waterfall. This stage is where the system design that has been designed previously is implemented into the program code. The system is performed with an object-oriented programming approach.

5. Testing and Analysis

Testing and analysis are carried out to determine whether the program code has been implemented properly and has no problems or vulnerabilities [20]. There are three tests conducted in this study, namely White-box, Black-box, and Usability testing. Then when the system has been developed, it is also necessary to simulate the use of Kanban on the system[21], The simulation is done so that no significant errors are found in the application of Kanban in the software that has been built.

6. Conclusion and Suggestion

Drawing conclusions and suggestions are based on the results of the entire system development process. Because of the outcomes, it can be obtained at the resulting core of the research process as a whole. Besides, conclusions can be extracted and evaluated to produce a suggestion for research that has been done so that other researchers can use it.

\section{B. Kanban}

Kanban (Japanese) has several meanings, namely a card or a signboard is a concept/method for visualizing work, making workflow visible, and reducing wasted work [9]. Kanban was first developed in 1940 by Taiichi Ohno to help Toyota to meet production efficiency for specific products based on market conditions, according to Kanban is one way to achieve JIT (Just in Time) or on time.

Kanban can be used in software development to visualize the various phases of the development process. Knowing all the tasks and stages of the job can be done with easier project monitoring[11].

Some components must be present to implement Kanban; the ingredients include 1. Kanban board; 2. Kanban card; 3. Limit/limit work in progress (WIP). Figure 3 is presented to make it easier to understand these three components. 


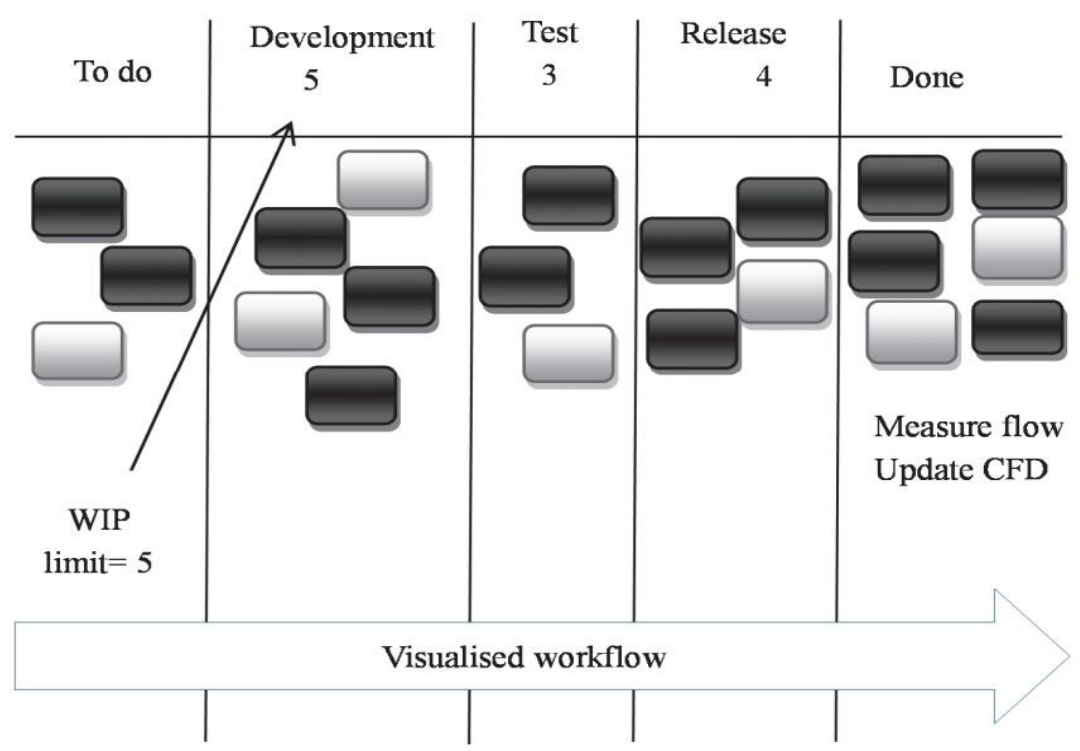

Figure 3. SimULATION OF APPLICATION OF KANBAN

1. Kanban Board

Kanban boards represent the steps that a task must pass before the job is declared complete.

Consider Figure 3, the field which is divided into five parts is called the Kanban board. On the far left is the board named "To do,". This board contains all the tasks/tasks that have been defined by the project manager. The project team has not done it, to the right, there is a board named "Development" where this board holds the current tasks in the development phase, continues to the rightmost board with the name "Done," this board contains all the functions/duties that have been completed through all stages / Kanban board.

2. Kanban Card

Kanban cards represent tasks that must be done by the project team. It can be seen in Figure 3 that on each Kanban board, a black or white card, this card represents the tasks that exist on a project. These cards are dynamic where when they are defined they will occupy the board named "To do," and if the team is ready to do the task, then one of the cards containing the job can be moved to the board named "Development" and so on until the card occupies the board "Done." Keep in mind that a card/task can be moved backward; this can occur, such as a problem occurs in a job so the project manager can move the card to the previous stage.

3. Limit Work in Progress (WIP)

Limit Work in Progress (WIP) is a number that states the limit of the number of kanban cards that can occupy aboard. It can be seen in Figure 3 above each board. A name is written that limits the number of tickets that can be placed on the board. 
INTENSIF, Vol.4 No.2 August 2020

ISSN: 2580-409X (Print) / 2549-6824 (Online)

DOI: https://doi.org/10.29407/intensif.v4i2.14320

\section{RESULT AND DISCUSSION}

\section{A. Requirement Engineering}

The system developed is a software project management system. The purpose of this system is to help control the running of a software project. This system has features to add project data, delete project data, change project data, manipulate client data, manipulate task data in each project, and also manipulate user data registered in the system. The use of this system begins with the login process. Users who can log in are only employees who have been created accounts by the admin/director company.

The elicitation method used to develop this system is by observation —observations made on the previous system that has been used by the company, the Orange Scrum system. Unlike the system that has been used previously by the company, this system adopts the use of Kanban for project management, and also the development of this system is done specifically for the company so that it is different from the previous system which is no subscription fee is required in this system.

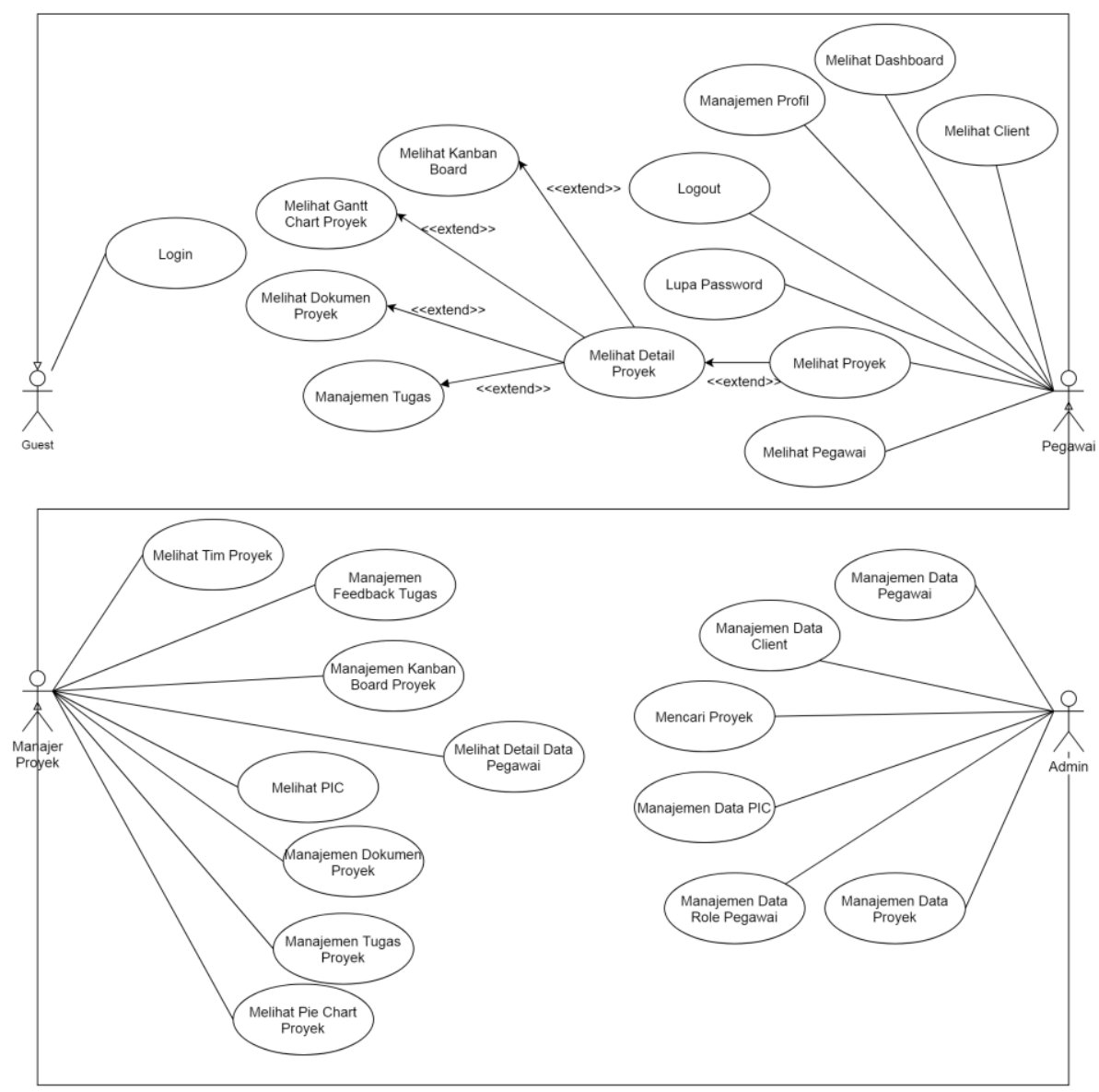

Figure 2. Use CASE Diagrams From PRoJect Management Systems 
There are four users in this system. These users are guests, employees, project managers, and admins. A summary of modeling the needs of this system can be seen in Figure 3. Because this system implements Kanban, this system has functions that support to carry out activities in accordance with the nature of the application of the Kanban method, which is in the form of cards, limits the work in progress, and is able to visualize all assignments at one time. Functions that fit this trait include making boards, erasing boards, making assignment cards, limiting the number of tasks on each board, moving assignments from board to board, and erasing assignments.[15]. This system is also equipped with a client data recording feature to find out who is requesting a project and who are the clients that have been served by the company.

\section{B. Plan}

The design that has been done produces four types of system design, namely data design, architectural design, component design, and interface design. Data design is the first design process that is used to obtain an overview of the relationship of each data in the system and is set forth in the PDM. Architectural design consists of sequence diagrams and class diagrams. Sequence diagrams are used to design in more detail how interactions between components of a function work. Class diagram is used to determine the class that will be used in the system. The component design contains algorithms for the main functions of this system. interface design is used to form the system page layout design.

The results of the architectural design process are three sequence diagrams of the three main features of this system and a class class that can be seen in Figure 4. There are nine controller classes derived from the CI_Controller class, namely the Pic, Project, User, Task, Employee, Client, Admin, Auth, and Board. There are seven model classes that are derived from the CI_Model class, namely the Client_model class, Feedback_model, Board_model, Employee_model, Pic_model, Task_model, and Project_model.

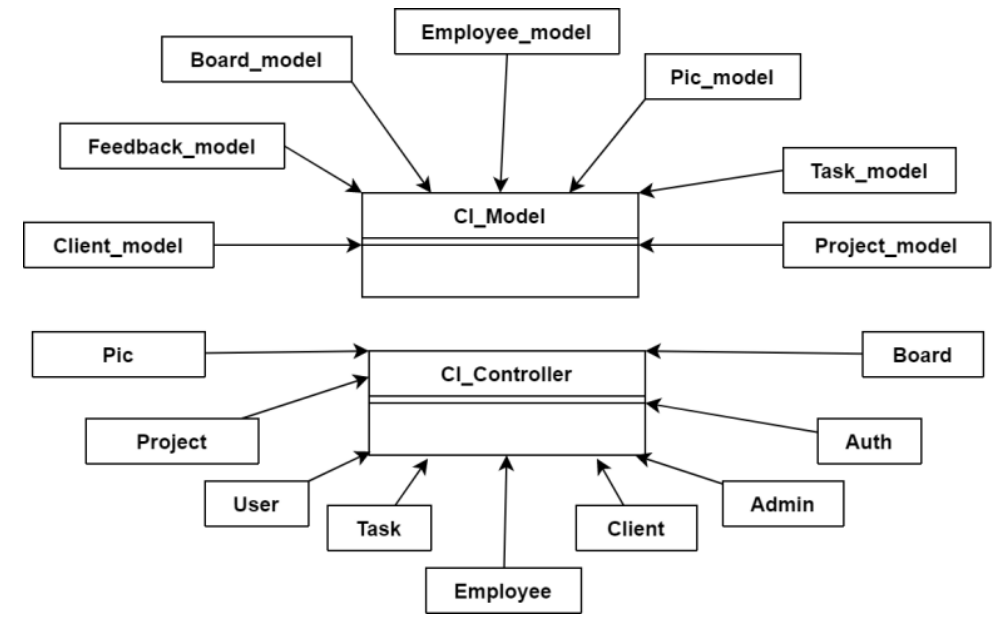

Figure 3. Class Diagram Of Project Management System 
INTENSIF, Vol.4 No.2 August 2020

ISSN: 2580-409X (Print) / 2549-6824 (Online)

DOI: https://doi.org/10.29407/intensif.v4i2.14320

The data design that was carried out produced the Physical Data Model (PDM). This PDM will be implemented as a database that is ready to use. PDM of this system can be seen in Figure 5. In accordance with the data analysis that has been done, nine entities are used as a database table design in this system. The database tables include pic tables, clients, docs add, projects, boards, users, user_role, tasks, and feedback. Component design produces three algorithm designs in the form of pseudocode of the three main functions that exist in the system. The three algorithms are adding project data, adding board data, and adding task data. Interface design produces three interface designs that are the main features of this system, namely the page interface to add project data, add board data, and add task data.

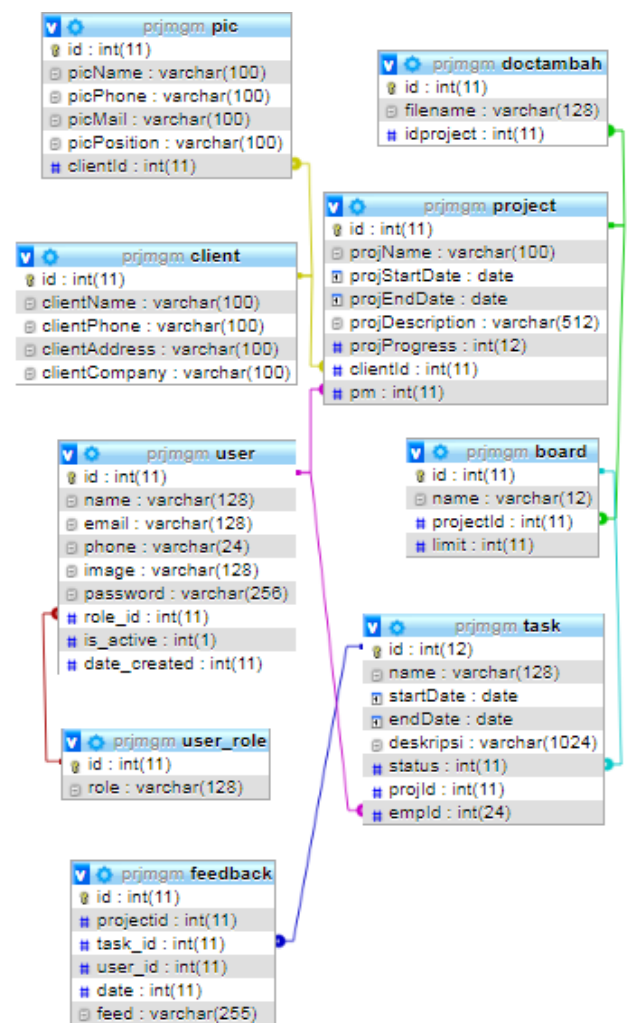

Figure 4. Physical Data Model Management System Project

Figure 7 is the design of an interface from the developed Kanban system page. This design is adapted to the three main Kanban artifacts mentioned earlier. Point 1 is the design of the Kanban board, Point 2 is the design of the assignment card, Point 3 is the field design to change the WIP limit. 


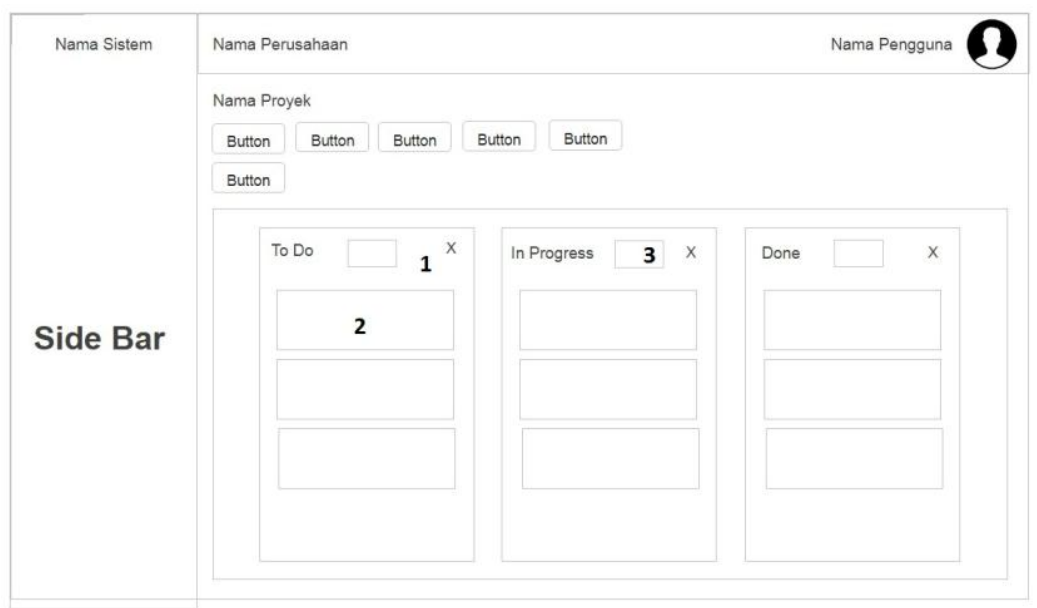

Figure 5. Design Of InTERface PAGe KANBAN PROJECT

\section{Implementation}

The results of the implementation of the project management system using the web-based Kanban method, resulting in the implementation of program code, data implementation, and implementation of interfaces in accordance with the design of the design results. The program code implementation uses PHP, HTML, CSS, Bootstrap framework, Javascript and also uses the CodeIgniter 3.1.10 framework. Codeigniter was chosen because it is easy to use, fast, and lightweight besides the developer does not need to write program code from the start. The Bootstrap Framework was chosen because it is easy to use to build front-end web pages easily[22]. This system database is implemented using MySQL DBMS with localhost server to facilitate data manipulation and storage. Access to the results of system implementation is done using the Google Chrome browser and Mozilla Firefox. An example of the results of the implementation of this system interface can be seen in Figure 8 .

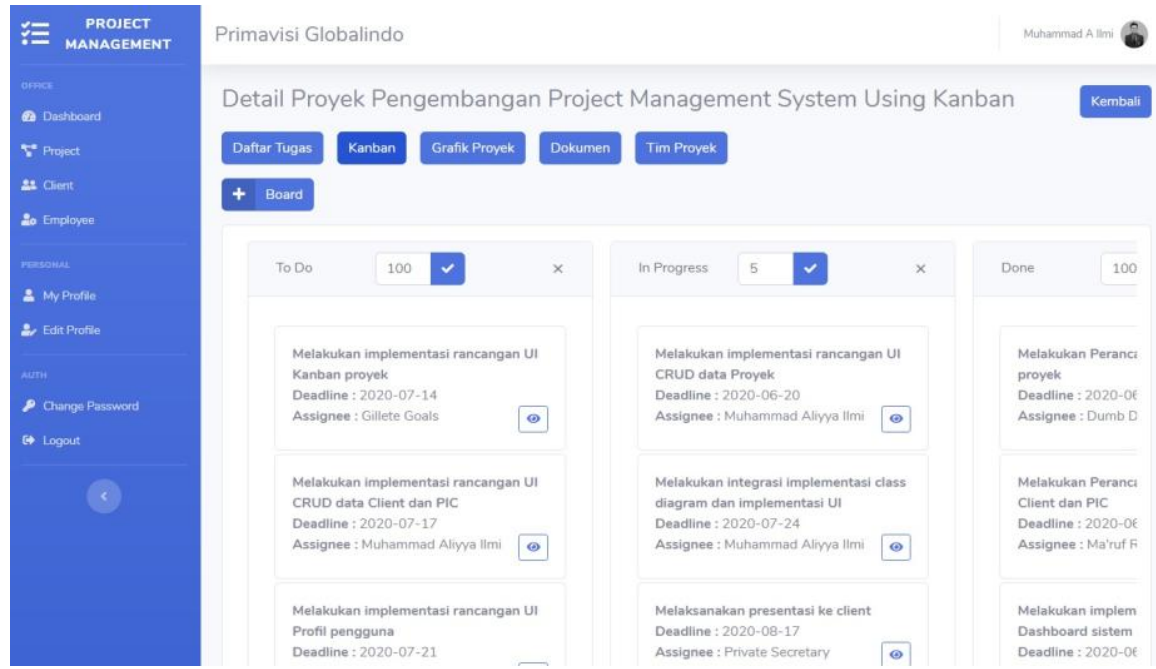

Figure 6. Picture Of ApPlication Of Kanban On The APPlication Of Project MANAGEMENT SYSTEM 
INTENSIF, Vol.4 No.2 August 2020

ISSN: 2580-409X (Print) / 2549-6824 (Online)

DOI: https://doi.org/10.29407/intensif.v4i2.14320

D. Testing and Analysis

The system is tested using three testing methods, namely unit testing with White-box testing, then validation testing with Black-box testing, and finally is usability testing with the SUS method.

1. White-box Testing

Base Path Testing technique testing from the White box testing method is the technique chosen to do this test. This technique was chosen because with this method the researcher can find out whether each path in a function can be said to be valid [20]. This stage contains testing on three methods, namely the add () method on the Project controller, the add method () on the controller Board, and the add method () on the Task controller. The results of unit tests on each method produce valid status on all paths tested, so that with this we get a value of $100 \%$ valid for all methods tested. One of the discussion and results of white-box testing can be seen in Figure 8 and Table 1.

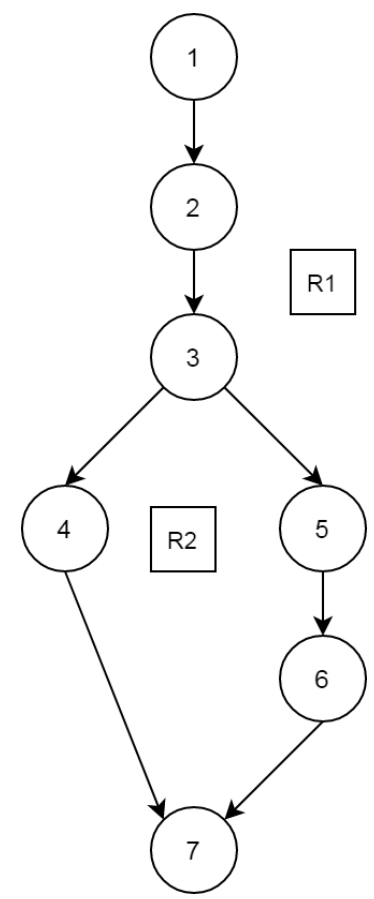

Figure 7. FlOW GRAPH METHOD ADDED TO BOARD ClASS

Figure 8 is a graph depicting the algorithm added method board flow. The flow graph will be used to determine the number of independent paths by using cyclomatic complexity calculations. The results of the added cyclomatic complexity flow graph method calculation contained in the Board class are described by the calculation below. The independent path obtained will be the basis for making test cases. The test results are presented in Table 1 .

$-\mathrm{V}(\mathrm{G})=$ number of region $=2$

$-\mathrm{V}(\mathrm{G})=$ number of edge - number of node $+2=7-7+2=2$

$-\mathrm{V}(\mathrm{G})=$ number of predicate node $+1=1+1=2$ 
INTENSIF, Vol.4 No.2 August 2020

ISSN: 2580-409X (Print) / 2549-6824 (Online)

DOI: https://doi.org/10.29407/intensif.v4i2.14320

- Independent lane 1: 1-2-3-4-7

- Independent lane 2: 1-2-3-5-6-7

Table 1. Test AdDED BoARd Test Results

\begin{tabular}{|c|c|c|c|c|}
\hline Lane & Test Procedure & $\begin{array}{c}\text { Expected-Test } \\
\text { Result }\end{array}$ & Test Result & Status \\
\hline 1 & $\begin{array}{l}\text { The add () method is } \\
\text { accessed by pressing } \\
\text { the "+ Board" button on } \\
\text { the project Kanban } \\
\text { page, then the actor } \\
\text { does not fill in the } \\
\text { name field and } \\
\text { immediately presses the } \\
\text { "Add" button. }\end{array}$ & $\begin{array}{l}\text { The add }() \text { method } \\
\text { is run under the } \\
\text { tested conditions, } \\
\text { then the system } \\
\text { displays a project } \\
\text { detail page and also } \\
\text { a message that the } \\
\text { board failed to be } \\
\text { added. }\end{array}$ & $\begin{array}{l}\text { The add () method is run } \\
\text { under the tested } \\
\text { conditions, then the } \\
\text { system displays a project } \\
\text { detail page and also a } \\
\text { message that the board } \\
\text { failed to be added. }\end{array}$ & Valid \\
\hline 2 & $\begin{array}{l}\text { The add }() \text { method is } \\
\text { accessed by pressing } \\
\text { the "+ Board" button on } \\
\text { the project's Kanban } \\
\text { page, then the actor fills } \\
\text { in the name field and } \\
\text { presses the "Add" } \\
\text { button. }\end{array}$ & $\begin{array}{l}\text { The add }() \text { method } \\
\text { is run under the } \\
\text { tested conditions, } \\
\text { then the system } \\
\text { adds the data board } \\
\text { to the database, and } \\
\text { displays the project } \\
\text { detail page and also } \\
\text { a message that the } \\
\text { board was } \\
\text { successfully added. }\end{array}$ & $\begin{array}{l}\text { The add () method is run } \\
\text { under the tested } \\
\text { conditions, then the } \\
\text { system adds the data } \\
\text { board to the database, } \\
\text { and displays the project } \\
\text { detail page and also a } \\
\text { message that the board } \\
\text { was successfully added. }\end{array}$ & Valid \\
\hline
\end{tabular}

2. Black-box Testing

Black-box testing is done to determine whether the program can run in accordance with the specified function, and has no errors when performing a particular function [20]. Black-box testing that has been done has obtained a $100 \%$ valid value for forty-nine functions in the system. The results of Black-box testing can be seen in Table 2 .

Table 2. BLACK-BoX TESTING RESUlT

\begin{tabular}{clc}
\hline \hline Functional No. & \multicolumn{1}{c}{ Test Case Name } & Test result \\
\hline SMP-F-1 & Login & Valid \\
SMP-F-2 & Forgot the password & Valid \\
SMP-F-3 & Logout & Valid \\
SMP-F-4 & Look at the Dashboard & Valid \\
SMP-F-5 & Search for Projects & Valid \\
SMP-F-6 & Add Project Data & Valid \\
SMP-F-7 & See Project & Valid \\
SMP-F-8 & Change Project Data & Valid \\
SMP-F-9 & Deleting Project Data & Valid
\end{tabular}


INTENSIF, Vol.4 No.2 August 2020

ISSN: 2580-409X (Print) / 2549-6824 (Online)

DOI: https://doi.org/10.29407/intensif.v4i2.14320

Table 3. Black-Box Testing Result [CONTINUE]

\begin{tabular}{|c|c|c|}
\hline Functional No. & Test Case Name & Test result \\
\hline SMP-F-10 & See Project Details & Valid \\
\hline SMP-F-11 & Add Task & Valid \\
\hline SMP-F-12 & See Task List & Valid \\
\hline SMP-F-13 & Updating Tasks & Valid \\
\hline SMP-F-14 & Deleting Task Data & Valid \\
\hline SMP-F-15 & See Job Details & Valid \\
\hline SMP-F-16 & Add Task Feedback & Valid \\
\hline SMP-F-17 & View Task Feedback & Valid \\
\hline SMP-F-18 & Removing Task Feedback & Valid \\
\hline SMP-F-19 & Add to Board & Valid \\
\hline SMP-F-20 & See Kanban Board & Valid \\
\hline SMP-F-21 & Change the Limit & Valid \\
\hline SMP-F-22 & Removing Board & Valid \\
\hline SMP-F-23 & See the Gantt Chart Project & Valid \\
\hline SMP-F-24 & See Project Pie Chart & Valid \\
\hline SMP-F-25 & Uploading Documents & Valid \\
\hline SMP-F-26 & View Project Documents & Valid \\
\hline SMP-F-27 & Read Project Documents & Valid \\
\hline SMP-F-28 & Deleting Document & Valid \\
\hline SMP-F-29 & Downloading Documents & Valid \\
\hline SMP-F-30 & Look at the Project Team & Valid \\
\hline SMP-F-31 & Add Client Data & Valid \\
\hline SMP-F-32 & Viewing Client & Valid \\
\hline SMP-F-33 & Change Client Data & Valid \\
\hline SMP-F-34 & Deleting Client Data & Valid \\
\hline SMP-F-35 & Add PIC Data & Valid \\
\hline SMP-F-36 & Look at PIC & Valid \\
\hline SMP-F-37 & Change PIC Data & Valid \\
\hline SMP-F-38 & Removing PIC Data & Valid \\
\hline SMP-F-39 & Add Employee Data & Valid \\
\hline SMP-F-40 & View Employee Data & Valid \\
\hline SMP-F-41 & Change Employee Data & Valid \\
\hline SMP-F-42 & Erasing Employee Data & Valid \\
\hline SMP-F-43 & See Employee Data Details & Valid \\
\hline SMP-F-44 & Add Employee Role Data & Valid \\
\hline SMP-F-45 & See Employee Role Data & Valid \\
\hline
\end{tabular}


Table 4. Black-Box Testing Result [Continue]

\begin{tabular}{clc}
\hline \hline Functional No. & \multicolumn{1}{c}{ Test Case Name } & Test result \\
\hline SMP-F-46 & Erase Employee Role Data & Valid \\
SMP-F-47 & Viewing Profile & Valid \\
SMP-F-48 & Change Profile Data & Valid \\
SMP-F-49 & Change Password & Valid \\
\hline
\end{tabular}

3. Usability Testing

Usability testing is done by involving a number of randomly selected respondents, respondents will be asked to try to use this system and assess it [23]. Usability testing is done using the System Usability Scale (SUS) method. The results of usability testing can be seen in Figure 9.

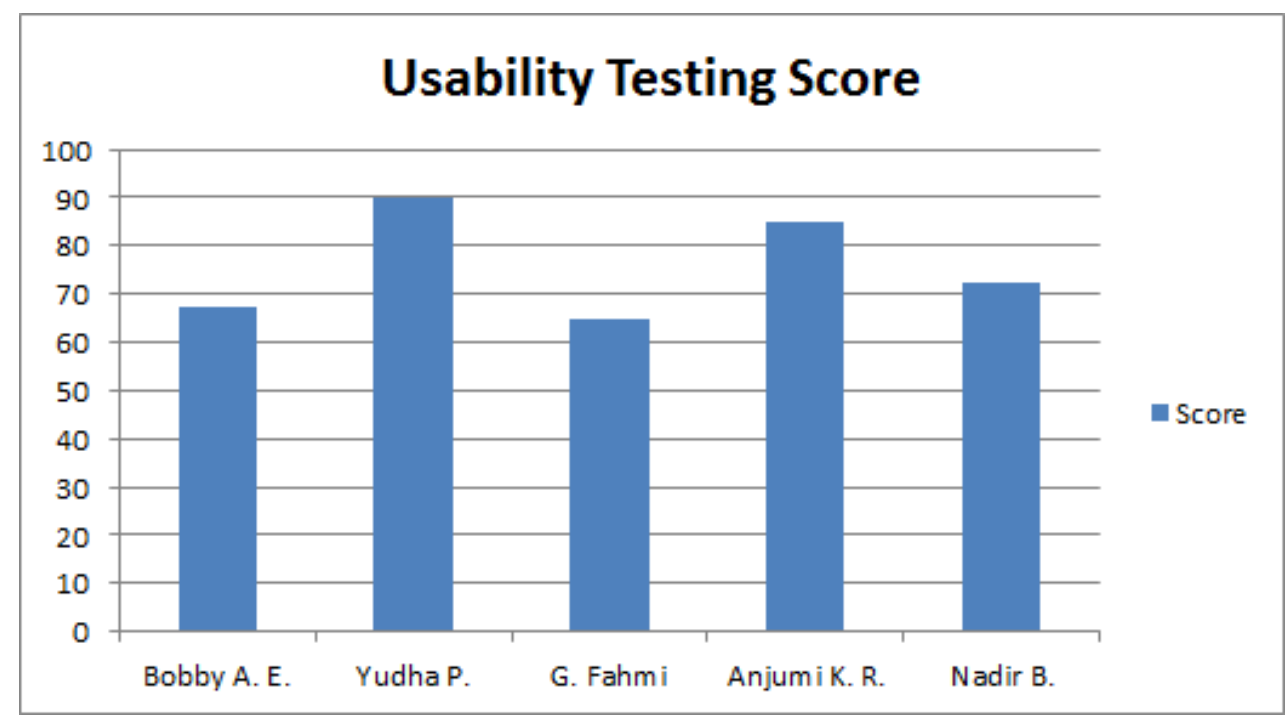

Figure 8. GRAPHICS OF USABILITY TESTING SCORES

Based on the usability test score chart data in Figure 11, the average value / score obtained by the five respondents was 76 . With these averages, it can be concluded that the system is classified as acceptable, which means the system has a sufficient and acceptable ease of value.

\section{CONCLUSION}

The Project Management System Using the Kanban Method developed has 49 functional needs and 1 non-functional requirement. The system has 9 tables to store data. The system is used by 4 users. Unit testing of the 3 main features of the system yields a validity value of $100 \%$. Validation testing of 49 functional systems produces a validity value of $100 \%$. Usability testing gets a value of 76 . Based on the results of the validation and usability test it can be concluded 
INTENSIF, Vol.4 No.2 August 2020

ISSN: 2580-409X (Print) / 2549-6824 (Online)

DOI: https://doi.org/10.29407/intensif.v4i2.14320

that the system is included in the acceptable / acceptable category and can help the company to handle the project. Suggestions for further development of this system is to provide an effort estimation feature to calculate project costs, clarify dependencies or relationships between tasks in a project, and develop systems using a more current and reliable framework.

\section{REFERENCES}

[1] I. Pihir and K. Brodar, "Impact of Project Management Education and ICT Usage on Project Success 1 . Project Management Education," no. March 2008, pp. 1-7, 2008.

[2] B. Hughes and M. Cotterell, "Software Project Management," Quality Management Journal, vol. 2, no. 1. McGraw-Hill, Berkshire, p. 396, 1999.

[3] Munir, Manajemen Proyek Perangkat Lunak. Bandung: UPI Press, 2015.

[4] R. D. Apriyanto and H. P. Putro, "Tingkat Kegagalan Dan Keberhasilan Proyek Sistem Informasi Di Indonesia," Semin. Nas. Teknol. Inf. dan Komun. 2018 (SENTIKA 2018), vol. 2018, no. Sentika, pp. 23-24, 2018.

[5] M. Lage Junior and M. Godinho Filho, "Variations of the kanban system: Literature review and classification," Int. J. Prod. Econ., vol. 125, no. 1, pp. 13-21, 2010.

[6] R. B. Wakode, L. P. Raut, and P. Talmale, "Overview on Kanban Methodology and its Implementation," IEEE Microw. Mag., vol. 3, no. 2, pp. 2518-2521, 2015.

[7] E. Leybourn, "Lean Kanban Practitioner," Www.Theagiledirector.Com, no. cc, p. 67.

[8] M. Ikonen, E. Pirinen, F. Fagerholm, P. Kettunen, and P. Abrahamsson, "On the impact of Kanban on software project work: An empirical case study investigation," Proc. 2011 16th IEEE Int. Conf. Eng. Complex Comput. Syst. ICECCS 2011, no. April, pp. 305-314, 2011.

[9] E. Corona and F. E. Pani, "A review of Lean-Kanban approaches in the software development," WSEAS Trans. Inf. Sci. Appl., vol. 10, no. 1, pp. 1-13, 2013.

[10] M. F. Fahat, B. Priyambadha, and F. Pradana, "Pengembangan Aplikasi Manajemen Proyek Perangkat Lunak Berbasis Scrum Studi Kasus CV. Nusantara Media Mandiri (CVNMM)," J. Pengemb. Teknol. Inf. dan Ilmu Komput. Univ. Brawijaya, vol. 2, no. 12, pp. 6627-6634, 2018.

[11] M. Alqudah and R. Razali, "A comparison of scrum and Kanban for identifying their selection factors," Proc. 2017 6th Int. Conf. Electr. Eng. Informatics Sustain. Soc. Through Digit. Innov. ICEEI 2017, vol. 2017-Novem, no. November, pp. 1-6, 2018.

[12] H. Lei, F. Ganjeizadeh, P. K. Jayachandran, and P. Ozcan, "A statistical analysis of the effects of Scrum and Kanban on software development projects," Robot. Comput. Integr. Manuf., vol. 43, pp. 59-67, 2017.

[13] J. Puche, J. Costas, B. Ponte, R. Pino, and D. de la Fuente, "The effect of supply chain noise on the financial performance of Kanban and Drum-Buffer-Rope: An agent-based perspective," Expert Syst. Appl., vol. 120, pp. 87-102, 2019.

[14] V. G. Aguilar-Escobar, S. Bourque, and N. Godino-Gallego, "Hospital kanban system implementation: Evaluating satisfaction of nursing personnel," Investig. Eur. Dir. y Econ. la Empres., vol. 21, no. 3, pp. 101-110, 2015.

[15] M. O. Ahmad, D. Dennehy, K. Conboy, and M. Oivo, "Kanban in software engineering: A systematic mapping study," J. Syst. Softw., vol. 137, no. November, pp. 96-113, 2018.

[16] K. Krishnaiyer and F. F. Chen, "A Cloud-based Kanban Decision Support System for Resource Scheduling \& Management," Procedia Manuf., vol. 11, no. June, pp. 14891494, 2017.

[17] K. Krishnaiyer, F. F. Chen, and H. Bouzary, "Cloud Kanban Framework for Service Operations Management," Procedia Manuf., vol. 17, pp. 531-538, 2018.

[18] A. S. T. Sofan Tohir, K. Kusrini, and S. Sudarmawan, "Implementasi Pengembangan 
Sistem Model Water Fall Untuk Data Warehouse Akademik," Intensif, vol. 1, no. 2, p. $108,2017$.

[19] L. S. Helling, "Perancangan Sistem Informasi Pelayanan Pelanggan Pada Citra Laundry Bogor," INTENSIF J. Ilm. Penelit. dan Penerapan Teknol. Sist. Inf., vol. 2, no. 1, p. 68, 2018.

[20] M. Kumar, S. Kumar Singh, and R. K. Dwivedi, "A Comparative Study of Black Box Testing and White Box Testing Techniques," Int. J. Adv. Res. Comput. Sci. Manag. Stud., vol. 3, no. 10, pp. 32-44, 2015.

[21] A. Tregubov and J. A. Lane, "Simulation of Kanban-based scheduling for systems of systems: Initial results," Procedia Comput. Sci., vol. 44, no. C, pp. 224-233, 2015.

[22] S. Susanto, B. Priyatna, and F. Aditya Permana, "Teacher Monitoring Application in Teaching Based on CodeIgniter Framework in High Schools," Buana Inf. Technol. Comput. Sci. (BIT CS), vol. 1, no. 1, pp. 12-15, 2020.

[23] N. M, A. Nagaraj, H. Gattu, and P. K. Shetty, "Research Study on Importance of Usability Testing/ User Experience (UX) Testing," Int. J. Comput. Sci. Mob. Comput., vol. 310, no. 10, pp. 78-85, 2014. 